\title{
BEHIND THE VEIL
}

\section{A Study of Chechen Black Widows' Web}

WHY IS THE PROPORTION OF FEMALE TERRORIST ATTACKS IN CHECHNYA HIGH COMPARED TO THE REST OF THE WORLD? CHECHNYA HAS UNDERGONE YEARS OF TRAUMA, AND A NUMBER OF CHECHen females, LABeled “Black Widows," have attempted to enact social Justice through TERRORISM. HOWEVER, WHY IS IT THAT FEWER FEMALES ARE ENGAGED IN TERRORIST ATTACKS IN OTHER WAR-STRICKEN PARTS OF THE WORLD? TO EXPLAIN WHY CHECHNYA IS AN OUTLIER IN THIS RESPECT, THIS ARTICLE WILL ANALYZE CHECHEN TERRORISM ON THE INDIVIDUAL, ORGANIZATIONAL, AND STRATEGIC LEVELS AND THEN COMPARE THESE FINDINGS TO THE TERRORIST DYNAMICS OF AL-QAEDA IN IRAQ. THIS COMPARISON WILL ALLOW THE READER TO GAIN A BETTER UNDERSTANDING OF THE TYPES OF ENVIRONMENTS THAT ARE MORE LIKELY TO FOSTER FEMALE PARTICIPATION IN TERRORIST ATTACKS. 
o

\section{INTRODUCTION}

During the winter of 20I4, as people from around the globe finalized their travel plans to watch the Sochi Olympics in Russia, the country was preparing itself for certain, more malicious visitors: Chechen Black Widows, who claimed they were going to make an appearance at the games. Although the Chechen insurgency ended in 2009 and the city of Grozny had risen from the ashes, the infamous female terrorists continued to partake in attacks and threatened the security of the Olympics. The city of Volgograd experienced this terrorist activity with full force. Between October and December of 2013, women carried out two of three suicide attacks by blowing themselves up on public transportation. ${ }^{\mathrm{I}}$ Certain Chechen female terrorists released videos, claiming that there would be bloodshed in Sochi as a means of revenge for the loss of their loved ones. Thus, the saga of the Black Widow once again captivated Russia and the world.

Female engagement in terrorist attacks is far from a rarity in Russia. Since the beginning of the Chechen insurgency in 2000 , women have participated in $80 \%$ of terrorist attacks and comprised $4 \mathrm{I} \%$ of suicide bombers. ${ }^{2}$ This is compared to female terrorism in Iraq, which accounted for only eight percent of all suicide bombings since $2003 .{ }^{3}$ The global count averages six percent female involvement, ${ }^{4}$ thus distinguishing the Chechen structure and strategy of female terrorism from the norm. This article seeks to explain this disparity and understand terrorism in Chechnya on the individual, organizational, and strategic levels compared to terrorism in other regions. The "indi-

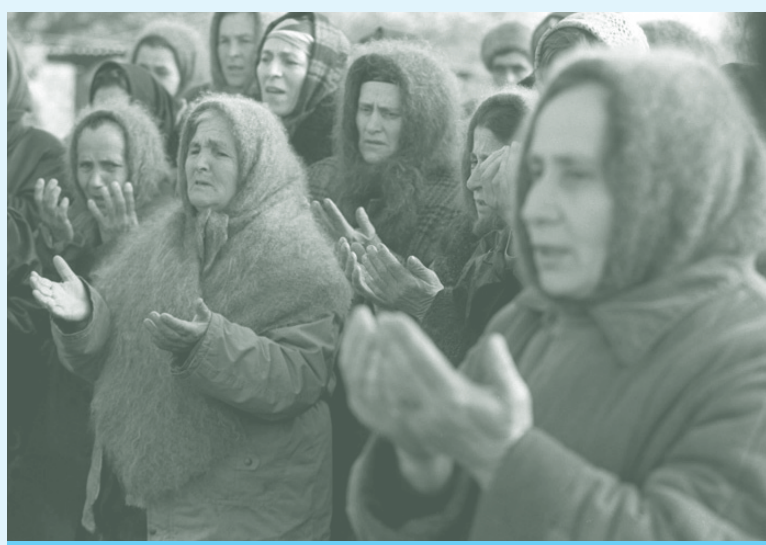

CHECHEN WOMEN PLEAD FOR RUSSIAN TROOPS NOT TO ADVANCE TOWARDS THE CAPITAL GROZNY (COURTESY OF WIKIMEDIA COMMONS) vidual level" refers to the personal reasons as to why one may join a terrorist organization, while "organizational" and "strategic" levels refer to the recruiting processes of the group and their strategies for carrying out successful attacks. Embedded in this research question are discrepancies regarding the degree of agency within a woman's decision to become involved in terrorism. Are women actively seeking out these organizations? Are the organizations seeking out the women? Or is it both? How does this differ from the dynamics of other organizations?

To begin unpacking these questions, this article will analyze the term "Black Widow" and explain the current studies on female terrorism in Chechnya. It will then break down its hypothesis and subsequently delve into a comparative case study of female terrorist participation in Chechnya and Iraq, testing the variables predicted to be factors for this gender divergence. The case studies will explore female liberties in the two regions, the proximity of females to recent political violence in the regions, ${ }^{5}$ and organizational dynamics of the Chechen terrorists in Russia and Al-Qaeda in Iraq. Finally, it will attempt to identify how distinct the Chechen case is. Studies show that female terrorism is on the rise. Would the answers to the questions posed help us understand why females participate in terrorist organizations, or is the Chechen case an outlier?

\section{WHAT IS A BLACK WIDOW?}

Before analyzing the current literature concerning female terrorism in Chechnya, it is important to first ask who the Black Widows are and where the term originates. In recent history, "Black Widow" has come to describe murderous women who have committed crimes directed at men in their lives. Just as the Black Widow spider poisons her male victim after mating and leaves him to an agonizing death, a woman described as a Black Widow is supposedly cruel and vengeful when carrying out her crime. This term appeared in the Russian media after to the Moscow Theatre Crisis, in which women dressed in black Islamic garbs comprised almost half of the 43 terrorists who took the auditorium hostage. ${ }^{6}$ Journalist Leela Jacinto commented on the event, "Covered from head to toe in all-black Islamic robes with only their determined, kohl-lined eyes showing, they quickly came to be called the 'Black Widows' as the horrified world watched a new Chechen female suicide squad in action last week." 7 The term, since 2002, has been blanketed over all Chechen female terrorists. The description of the Chechen female terrorists is an interesting play on words, as it is meant to not only capture their 
crimes, but their garments and grief. The Chechen female terrorists are usually dressed in their full length black hijabs when recording a propaganda video for the public and carrying out attacks. Additionally, the term is meant to describe the sorrow and grief of Chechen females, as many of the terrorists lost their husbands or loved ones in the Chechen War. Thus, this label stresses the emotional component of female terrorism in Chechnya and adds the stigma that Chechen female terrorists are crazed, desperate widows.

\section{COMPETING ARGUMENTS}

Since the rise of female terrorism in Chechnya, scores of scholars and journalists have attempted to explain what has led Chechen females to become involved with terrorist organizations. The theories of female involvement vary in the degree of activity and passivity throughout the women's recruitment process, and thus vary in the reasoning as to why women participate in attacks.

The "Avenger Theory," devised by the Russian media, branches off the "Black Widow" stigma and implies that women are crazed with revenge and are thus lured into terrorist organizations. As stated, the notion that Chechen terrorists are drowned in their revenge and grief became prominent after the Moscow Theatre Crisis. Hostages recounted the women repeating similar stories: "My whole family was killed. I have buried all my children. I live in the forest. I have nowhere to go and nothing to live for." ${ }^{8}$ Thus, it is believed and relayed by the media that emotions and vengeance are the paramount reasons behind females turning to terrorism. The "Avenger Theory" is used to take away the decision-making power of the female and delegitimize the Chechen terrorist organizations. According to the theory, women are easily influenced by terrorists groups, whose "recruiters lurk within an atmosphere of emotional fervor, and take advantage of personal loss." 9 Therefore, this theory identifies the Chechen women's grief as the catalyst for their involvement in terrorism.
The "Avenger Theory" has prompted many refutations, which are most clearly summarized by scholars Anne Speckhard and Khapta Akhmedova. Speckhard and Akhmedova created a comprehensive list of all the Chechen terrorist attacks between 2000 and 2005. After conducting numerous interviews with the family members of 26 of the 43 female terrorists, the scholars affirmed that revenge and trauma were factors inciting female membership to terrorist organizations, but with certain reservations. First, these emotions are not elements specific to females, as "the motivational mechanism for seeking out a terror group generated at first by deep personal traumatization did not differ by gender in any way. Both genders in [the sample had suffered violent losses of family members]." ${ }^{\text {Io }}$ Second, the stress on emotions undermines the agency of the women. According to their studies, there was "strong willingness to martyr oneself on behalf of one's country and independence from Russia" with motives of enacting social justice and expressing their political grievances. ${ }^{\text {II }}$ The scholars additionally stress the idea that trauma is not enough of a reason for the amount of female participation in Chechen terrorist attacks-the Chechen organizations have capitalized on the stigmas that have been created from the "Avenger Theory" to create psychological fear. The scholars state that "the use of women bombers on planes, trains, and in the subways has implanted in Russians a feeling of all-pervasive danger, potentially presenting anytime and anywhere, from the gentler of genders." ${ }^{2}$ There are numerous other theories worth mentioning before introducing the paper's argument. Alisa Stack's study for the National Defense Unit focuses on the organizational level of terrorism. She emphasizes the idea that women are used as a last resort, as many men have been taken hostage and are always the first to be interrogated. ${ }^{13}$ Another argument popular among Russian journalists and politicians is the "Zombie Theory," which asserts that women are drugged to perform these attacks against their own wills.

"Trauma and independence created fertile ground for terrorism, and more importantly, there was an organization that quickly understood why and how exploiting females in their terrorist plans was beneficial." 
This article focuses on uncovering the reasons as to why the Chechen case is an outlier concerning gender norms and terrorism. Many of the competing arguments explain why females join or are forced into performing terrorist acts. However, most do not acknowledge what makes the Chechen case so different from other terrorist organizations. Many other regions have had political turmoil and to the public's captivation of the "crazed widow" terrorists of Chechnya. Thus, the notion of the "Black Widow"which is bolstered by the "Avenger Theory"-has become a double-edged sword for the Russians. The term was meant to delegitimize the Chechen terrorists as cowards who hide behind women, but at the same time, the idea of a Black Widow gave the terrorist organization a reason to

\section{"While Al-Qaeda in Iraq has remained wary about using female terrorists, Chechen terrorists are able to carry out attacks without extensive worry about ideological backlash from Al-Qaeda Central."}

women who want to enact their own vision of social justice. It is the organization and its strategies that make the real difference. Speckhard and Akhmedova prove through their interviews that the "Avenger Theory" does have some credibility; however, as stated, grief is not the raison d'être for female terrorism in Chechnya. A "perfect storm" has occurred. On an individual level, the personal proximity of females to the gruesome Chechen War has created a battlescarred generation of women. Also, Chechen women have more liberties than many of their Arab sisters living in regions where terrorism is present. This factors into terrorism because their independence has allowed them to react to their grievances with options. While most Chechen women opened businesses and turned new leaves, others used their emancipation to seek terrorist organizations. However, it is important to note that while these factors have influenced how females turn to terrorism in Chechnya, my argument stresses the decisions made by the Chechen leadership as the most important aspect of Chechnya's heightened instances of female terrorism.

Additionally, it is important to focus on the importance of the organizational and strategic levels and analyze the dynamics of the Chechen terrorist organization. As Speckhard and Akhmedova have stated, trauma alone is not enough for female participation in terrorism. ${ }^{14}$ Thus, this is where the "perfect storm" comes into play and where mere thoughts are actualized. The strategies of Chechen organizations are the main reasons why females are employed in such acts. The organization has used women from the beginning of its insurgency because, like Speckhard and Akhmedova have stated, the prominence of Black Widows in Russia has become a self-fulfilled prophecy due continue using female terrorists. Shamil Basayev, who led the Chechen insurgency until his death in 2005, understood the captivation and fear that came along with the usage of the term "Black Widows." He additionally understood very early on the degree of costly signaling imposed by a female suicide bomber, and how employing females as suicide bombers had many benefits which translated to economic success. Thus, the individual situation of the women has created an environment for female terrorism; however, the organizational and strategic level is where the real difference is made and explains why females have a much higher presence in Chechen terrorist attacks.

\section{RESEARCH METHODS}

A spatiotemporal case study based on empirical and theoretical evidence will be used to reach a proper conclusion to this research question. The first analysis will be of the Chechen case and subsequently compare the Chechen case to female terrorism within Al-Qaeda. Al-Qaeda is an organization with many different cells. Al-Qaeda will be studied within Iraq, where terrorist activity has been rampant for the past ten years.

The Chechen case study will span over five years, from 2000 to 2005 . Not only were these the five years with the most instances of terrorism, ${ }^{15}$ but they are also the range of dates with the most precise data, offered by Speckhard and Akhmedova, about Chechen suicide attacks. Female trauma and women's liberties within the region as well as the strategies of the Chechen organization will be analyzed. 
The Chechen case will be compared to Al-Qaeda in Iraq because Al-Qaeda falls within the gender norm and is representative of a region that has considerable terrorist activity. The Iraq analysis will focus on the years between 2003 and 2008 , as terrorism was most prominent during this time period. ${ }^{16}$ This information is the best platform for critical assessment of its strategies, which will give clues as to why or why not Al-Qaeda in Iraq chose to use female terrorists. Additionally, the cultural differences concerning gender and the role of women may indicate why females turn or do not turn to terrorism.

\section{ROOTS OF VIOLENCE}

To understand the plight of Chechen female suicide bombers, one must first understand the Chechen War and the proximity of Chechen women to the horrific violence between Chechnya and Russia. In the past 20 years, Russia and Chechnya have undergone two gruesome wars and a bloody insurgency that had tremendous impacts on the Chechen population. Animosity between Russia and Chechnya dates back to the time of the tsars. However, the first modern war began in 1994 as a result of attempts by the Chechens to create a sovereign state after the dissimilation of the Soviet Union. Laura Sjoberg explains, "The Chechen conflicts are connected to the broader problems of post-communist transformation in the former USSR and as such hold substantial symbolic value for Russia's state legitimacy." ${ }^{17}$ Thus, the stakes of the first Chechen Wars were substantial vis-á-vis Russia, as it tested the Federation's ability to hold together a functioning state. Guerilla warfare lasted for almost two years. "Peace" arrived in 1996, but the ceasefire did not last long, and in I999, fighting resumed. The second Chechen war had its roots in the radicalization of a small group of Chechen Islamists, led by Dokka Umarov, who invaded Dagestan with the goal of creating an Islamic State. After a full-scaled Russian intervention and a horrific death toll, the Federation claimed complete control over the region in May 2000. ${ }^{18}$ Although the "battle phase" had ended, violence associated with terrorism and counterterrorism continued until 2009 , with the heaviest fighting until 2003. It is estimated that in the past 20 years, over $20 \%$ of the Chechen population has been killed. ${ }^{19}$

\section{CHECHEN WOMEN'S PROXIMITY TO VIOLENCE}

The Chechen Wars have taken an extremely large toll on all of the population. Significantly, women suffered the brunt of this violence, which provides one explanation as to why Chechen women participate in terrorism within the region. Most women were not fighting on the front lines in a conventional sense, but due to the nature of guerilla warfare, the collateral damage that affected noncombatants, and the complete absence of human rights, there was no way to hide from the battlefield. While certain wars have designated combat zones, this was not the case for Chechnya. The roads of Grozny soon turned into the pits of hell. Paul Murphy explains, "She's been bombed, shelled, strafed, mined, shot, robbed, left homeless, imprisoned, tortured, kidnapped, raped, victimized, and had her husbands, sons, and daughters taken from her." ${ }^{20}$ Russian violence towards noncombatants was ruthless. In addition to extreme brutality, most Chechen women experienced excruciating loss. Of the 26 families of female suicide bombers interviewed by Speckhard and Akhmedova, 24 claimed

\begin{tabular}{|c|c|c|c|c|c|}
\hline $\begin{array}{l}\text { Marital } \\
\text { Status }\end{array}$ & $\begin{array}{l}\text { Education } \\
\text { Completed }\end{array}$ & $\begin{array}{l}\text { Economic } \\
\text { Status }\end{array}$ & $\begin{array}{l}\text { Previous } \\
\text { Religiosity }\end{array}$ & $\begin{array}{l}\text { Relation to } \\
\text { Wahhabism }\end{array}$ & Trauma* \\
\hline 13 - single & $\begin{array}{l}17 \text { - high } \\
\text { school }\end{array}$ & $2-$ poor & $\begin{array}{l}22-\text { secular } \\
\text { Muslims }\end{array}$ & $\begin{array}{l}19-\text { connected } \\
\text { after traumas }\end{array}$ & $\begin{array}{l}12-\text { more than one } \\
\text { family member killed }\end{array}$ \\
\hline 3 - married & 1 - college & 14 - middle & $\begin{array}{l}4 \text { - traditionally } \\
\text { religious }\end{array}$ & $\begin{array}{l}7-\text { connected } \\
\text { through family }\end{array}$ & $\begin{array}{l}4 \text { - father or mother } \\
\text { was killed }\end{array}$ \\
\hline 4 - divorced & 5-university & $9-$ good & & & 6 - brother killed \\
\hline 5 - widowed & 3 - in college & 1 - high & & & $1-$ husband killed \\
\hline 1 - remarried & & & & & $\begin{array}{l}3 \text { - family members } \\
\text { arrested or disappeared } \\
\text { after arrest }\end{array}$ \\
\hline & & & & & $\begin{array}{l}2 \text { - general societal } \\
\text { traumas }\end{array}$ \\
\hline
\end{tabular}

DATA FROM 26 FEMALE TERRORISTS THAT PERFORMED TERRORIST ACTS BETWEEN 2000-2005. 
i that the female suicide bomber had suffered a personal loss. Half had lost more than one family member. Therefore, understanding the proximity of Chechen females to the wars is the first factor in understanding female suicide bombers in Chechnya on an individual level.

In addition to the trauma experienced by Chechens, women in the region are relatively independent and have become more so since the wars. This proves to be a factor when considering the participation of female suicide bombers because it allows for a degree of agency within the woman as she deals with avenues to express the trauma she has undergone. Speckhard explains, "While family structure is still traditional, it is common for Chechen women to attend university." ${ }^{21}$ The female suicide bombers reflect this fact, as $65 \%$ of the studied bombers had finished high school and the other $35 \%$ were either currently in college or had finished their studies. ${ }^{22}$ Further information about the autonomy of the Chechen females can be seen in the table on the previous page. The literacy rate of Chechen women in particular is unknown, but the literacy rate of Chechnya is around $93 \% .^{23}$ In addition to their relatively high educational and literacy status, a large number of women in Chechnya have become the breadwinners of their households, as many male family figures have either been murdered or gone missing. Since the Chechen Wars, it is very common for females to be part of the entrepreneurial class. Nonprofits such as the International Medical Corps have supported a number of businesses started by women since the end of the turmoil. ${ }^{24}$ Thus, the fact that women in Chechnya have certain degrees of freedom should be taken into account when analyzing female suicide bombers because it demonstrates the options that women have had in the post-War Chechnya. The majority of women have turned new leaves and have used their independence in beneficial ways. However, independence has also provided women with the option to turn to other, more malicious means to achieve what they believe to be social justice or revenge.

Devastation and independence are two factors that explain the individual level for Chechen female suicide bombers. However, the decisions made on the organizational level appear to be the most important aspects of the employment of female suicide bombers. Marc Sagemen, in his study "Joining the Jihad" explains that recruitment of suicide bombers is a top-down process. The organization decides which bombers allow for the costliest signaling. ${ }^{25}$ Nabi Abdullaev furthers this claim when describing the Chechen organization by stating that "it is the existence of the [Chechen] organization, rather than the existence of grievances, that determines the occurrence, scope, and pattern of suicide attacks." ${ }^{26}$ The factors on the individual level prove that there are many women who are willing to sacrifice themselves for Chechen autonomy or social justice causes, and they have the independence to make these decisions. Thus, while there is a high degree of autonomy in the Chechen women's decision to turn to terrorism, the organization actualizes this potential.

The Chechen terrorists, from the start of their insurgency, have employed females for a number of reasons. First, the Chechen terrorists have used the term "Black Widow" to their advantage and have understood the fear created from the media hype. As Margaret Thatcher stated, "The hijacker and the terrorist thrive on publicity: without it, their activities and their influence are sharply curtailed." ${ }^{27}$ Thus, the media is a very important factor, as terrorist organizations want to attract the most attention as possible. The idea and stigma of Black Widows has become an international phenomenon since the Moscow Theatre Crisis, inciting high levels of fear among Russians. Abdullaev explains, "The media is sucked in by the drama of self-sacrifice for a cause, with the centrality of women having a force-multiplying effect on the viewer's consciousness" and therefore, for the Chechen terrorist organization, "the ominous title of 'Black Widows' by the Russian media has proved to be paying off." ${ }^{28}$ Thus, the idea of the Black Widow has become a self-fulfilling prophecy, as the media hype has created incentive for the Chechen organization to further employ female suicide bombers.

Second, and most importantly, Chechen terrorist leader Shamil Basayev realized the effectiveness associated with female suicide bombers. These benefits include low degrees of suspicion and high degrees of precision. In addition, the more effective a suicide attack is, the more money a terrorist organization will receive from outside donors, including Al-Qaeda and other extremist Islamist organizations. ${ }^{29}$ Thus, this has created additional motivation for the usage of female suicide bombers. The Russians' brutality and crackdown on Chechen terrorists forced Basayev and terrorist organizations to find cunning ways to employ terror because "Chechen men between the ages of 16 and 60 have been the targets of detention and interrogation." ${ }^{3 \circ} \mathrm{As}$ scholar Lindsey O'Rourke has stated, females can hide suicide packs and thus pass through security more easily. Thus, the Chechen terrorists have understood from the beginning of their insurgency that employing females in their terrorist attacks has numerous benefits. The case 
study above proves that there are a number of factors that have created a "perfect storm" for the implementation of female suicide bombers in Chechnya. Trauma and independence created fertile ground for terrorism, and more importantly, there was an organization that quickly understood why exploiting females in their plans was beneficial.

\section{WHY IS THE CHECHEN CASE AN OUTLIER?}

If female terrorism is so effective why is it still relatively uncommon? What is it about the Chechen case that has rendered it an outlier? Female terrorism is on the rise, and this insinuates that terrorist organizations are starting to realize the effectiveness of a female suicide bomber. However, the proportion is still much lower than that in Chechnya. There is a fundamental difference in either the lifestyles of females or the way that terrorist organizations run their operations. A study of female terrorism in Iraq between 2003 to the present will aid us in this endeavor. This timeframe demonstrates that lack of female autonomy and differing opinions among Al-Qaeda leaders have led to wariness in allowing women to engage in terrorist attacks.

\section{THE RISE OF AL-QAEDA IN IRAQ}

Before delving into female terrorism within Iraq, it is first important to gain an understanding of the political landscape of the nation. Iraq has been subject to invasion and political instability since the fall of the Ottoman Empire in the 2oth century. Recent turmoil ironically came in the form of the American led "Operation Iraqi Freedom." The Baathist regime soon fell, and its leader, Saddam Hussein, was captured in December of 2003. Although Americans thought they had captured the enemy, a more lethal foe began to rise-Al-Qaeda in Iraq. Bruce Riedel explains:

Al Qaeda also moved swiftly to develop a capability in Iraq, where it had little or no presence before 9/II...On February II, 2003 , bin Laden sent a letter to the Iraqi people, broadcast via satellite network al Jazeera, warning them to prepare for the 'Crusaders war to occupy one of Islam's former capitals, loot Muslim riches and install a stooge regime to follow its masters in Washington and Tel Aviv. ${ }^{3+}$

Iraq soon became a hub for international terrorism as jihadists from around the world came to fight under Al-Qaeda. The political landscape for the past ten years has been extremely unstable, as its citizens have been plagued by both a discriminating Shia leader, Nouri Al-Maliki, and the terrorist organization Al-Qaeda in Iraq.

\section{THE ROLE OF WOMEN IN IRAQ}

Like Chechen females, Iraqi females have undergone extensive trauma and the loss of loved ones. However, due to cultural differences and lack of rights, women do not appear to have as many choices as Chechen women do to either act on their grief or to turn their lives around. For one, the education and literacy rates are much lower among women in Iraq. UNESCO reports, "Significant gender disparities are also a matter of concern with illiteracy rates reaching higher than 47 percent among women in some areas." ${ }^{2}$ Like Chechen women, Iraqi women have undergone extensive trauma in the past fifteen years inflicted at the hands of American soldiers, Iraqi sectarian powers, and terrorists. However, when one loses a husband, "it is considered dishonorable for a widow to remain alone, and families are expected to provide for her and her children." ${ }^{33}$ Women whose families cannot provide for them are left with few options, as the Iraqi system is extremely patriarchal. The International Red Cross Fund reported, "Without a male relative, a woman lacks economic, physical, and social protection and support" and "social barriers and discrimination limit women's access to work." 34 Thus, while many Chechen women became even more independent after the war and became the breadwinners of the households, the Iraq War has only further tied Iraqi women to male relatives.

On an individual level, the trauma factor is present. However, there is a clear lack of freedom among Iraqi women. This factors into Iraq's minimal female terrorist presence because Iraqi women, unlike Chechen women, may not have the resources or connections to seek out terrorist organizations. Thus, there appears to be a link between female emancipation within Iraq and female participation in terrorist attacks in Iraq.

\section{FEMALE TERRORISM AND AL-QAEDA IN IRAQ}

As demonstrated in the Chechen case, the dynamics of the terrorist organization appear to have more weight when understanding the makeup of those involved in suicide attacks rather than the individuals that decide to join. Therefore, it is necessary to study the organizational structure and beliefs of Al-Qaeda in Iraq, a direct branch of Al-Qaeda. As stated, since the Iraq war, there has been a large influx of jihadists fighting under Al-Qaeda leadership. Because Al-Qaeda is a primarily religious organization, the group has certain ideological views that affect its strategies. One of these views is that women should not be per- 
9 mitted to implement jihad. A letter by an Al-Qaeda leader, Yusuf al-Ayeri stated, "We don't want [women] to enter the battlefield during strife. We want [women] to emulate our female ancestors in their incitement to jihad, their preparedness for this, their patience and passion." ${ }^{35}$ However, since 2003 , the late leader of Al-Qaeda in Iraq, Al-Zarqawi, has utilized females in his terrorist attacks. Al-Zarqawi's decision created much negative backlash among the AlQaeda community, as the idea of female suicide bombers was, and remains, a very controversial topic among AlQaeda leaders. Numerous fatwas and counter fatwas have been issued over the topic. ${ }^{36}$ Mia Bloom, in her work Female Suicide Bombers, A Global Trend, states, "The use of women remains a point of contestation among different streams of Salafism in Al-Qaeda Central ... ${ }^{37}$ As long as the majority of suicide bombers in Iraq come from the Gulf, the numbers of women will remain low since neither the Saudis nor other more conservative Wahhabis will permit women to go on jihad." ${ }^{8} 8$ This strengthens the notion that the number of females participating in terrorist attacks depends on the organization, and furthermore, who is leading the organization at the time. Thus, it appears that on an individual level, Iraqi women do not have the freedom to network and independently seek out terrorist organizations, and on an organizational and strategic level, the use of female terrorists is limited as Al-Qaeda leaders still find it to be a very controversial topic.

\section{CONCLUSIONS AND LOOKING FORWARD}

Chechen female participation in terrorism, when compared to other regions in the world, is an anomaly for individual and organizational reasons. Upon further analysis, much of the reason the region is an outlier is due to the "Black Widow" stigma created by the media, which has generated a lot of hype and encouraged the terrorist leadership to further employ women in battle. The Chechen terrorist group has realized that using females in attacks brings attention, fear, and efficient results.

The personal level appears to be important in the Chechen case, as women have had the liberty to seek out and fight for terrorist groups. Per Speckhard and Akhmadova, it can be concluded that most women that do participate in Chechen terrorist cases are self-recruited, which helps understand their purpose for terrorist involvement. While the "Avenger Theory" is correct in a sense, it is not specific to women, and it does not speak to the larger political purpose that many of the Chechen women have when carrying out these attacks.
The passive and active notions remain less clear in Iraq. There is insufficient evidence to show whether the women involved in terrorism seek out the organization or if the organization recruits them. However, the lack of freedom among women in Iraq does appear to be linked to the low level of female involvement in Iraqi terrorist organizations. Thus, the individual level does appear to have a certain amount of influence when explaining female participation in terrorist attacks.

When comparing the organizational and strategic level of Chechnya and Iraq, there are clear differences wedged between the two organizations. The Chechen struggle, although financially linked to Al-Qaeda, has remained quite autonomous in its decision-making strategies, and the targets of their attacks have been Russian. Thus, while AlQaeda in Iraq has remained wary about using female terrorists, Chechen terrorists are able to carry out attacks without extensive worry about ideological backlash from Al-Qaeda Central. These differences demonstrate organizations' powerful effects on the degree of female terrorism within a terrorist group.

Looking forward, it appears that for at least a while, Chechnya will remain an outlier. As demonstrated in the Sochi Olympics, female terrorism in the Northern Caucuses is still present and the hype of the Black Widow remains influential. Chechnya is growing and healing from the extensive damage from the Wars. However, terrorists have diffused into neighboring Dagestan and Ingushetia. Thus, it appears that female terrorism will still be used as a strategy for the Chechen organization. Concerning Iraq and many other parts of the Middle East, it appears that the percentage of females employed as terrorists will remain low for as long as female terrorism is controversial. As Mia Bloom has stated, many jihadists fighting for Al-Qaeda come from all over the world, and thus, there is no dearth of male recruits. ${ }^{39}$ However, the landscape of terrorism is changing in Al-Qaeda. For example, Al-Qaeda in Iraq recently broke away from Al-Qaeda central and has created a new organization, the Islamic State. Led by Abu Bakr AlBaghdadi, it will be interesting to see if ideological concerns surrounding female terrorism will become less controversial now that the organization is independent from the Al-Qaeda Central leadership. 


\section{ENDNOTES}

I. Tsvetkova, 20I3

2. University of Chicago.

3. Ibid.

4. Ibid.

5. By recent political violence, I refer to the effects of the

Chechen War in Chechnya and in Iraq.

6. CBS News, 2003.

7. Jacinto, 2002

8. Stack, 2009 .

9. Sjoberg and Gentry (IOI)

Io. Speckhard and Akhmedova (7I)

II. Speckhard and Akhmedova (70).

I2. Speckhard and Akhmedova (72)

I3. Stack-O'Connor, 2007.

I4. Speckhard and Akhmedova (70).

I5. University of Chicago.

I6. Ibid.

I7. Sjoberg and Gentry (90).

I8. Gilligan (I-20).

I9. Sjoberg and Gentry (90).

20. Murphy (28).

2I. Speckhard and Akhmedova (72).

22. Speckhard and Akhmedova (66).

23. Hanemann, 2006

24. Murphy (228).

25. Sagemen (I23).

26. Abdullaev, 2007.

27. Thatcher, 1985.

28. Abdullaev, 2007.

29. Murphy (2IO).

30. Stack-O'Connor, 2007.

3I. Riedel, 2007.

32. UNESCO, 2014.

33. International Committee of the Red Cross in Iraq, 2009.

34. Ibid.

35. Al-Saleh, 2014

36. Ibid.

37. It is important to note that although Chechen terrorists have been trained by Al-Qaeda members and do adhere to Wahhabi ideology, the group is not a part of Al-Qaeda central. The leaders of the Chechen organization, although Islamic, are not directly tied to Al-Qaeda central and thus have been able to act with more autonomy than other Islamists groups.

38. Bloom, 2007.

39. Ibid.

\section{REFERENCES}

Abdullaev, Nabi. "Unraveling Chechen 'Black Widows'” $R U$ Studies and Research Centre. N.p., n.d.

Al-Saleh, Huda. "The Women of Al-Qaeda." Asharq AlAwsat. N.p., 5 Jan. 2014.
Bloom, Mia. "Female Suicide Bombers, a Global Trend?" Daedalus (2007): 8.

Bowers, S.R., A.A. Derrick, and M.A. Olimov. "Suicide Terrorism in the Former USSR." Mothers, Monsters, and Whores. By Laura Sjoberg and Caron E. Gentry. New York: Zed, 2007. IOI.

Chicago Project on Security and Terrorism. University of Chicago, 20I4

Gilligan, Emma. Terror in Chechnya. Princeton, NJ: Princeton UP, 2010.

Hanemann, Ulrike. Literacy in Conflict Situations. UNESCO. United Nations, Mar. 2006.

Jacinto, Leela. "Chechen Black Widows Bring New Fears." $A B C$ News. N.p., 29 Oct. 2002.

"Literacy and Non-Formal Education in Iraq." UNESCO Office for Iraq. United Nations, n.d.

Murphy, Paul. Allah's Angels. Annapolis, MD: Naval Institute, 2 OIо.

Riedel, Bruce. "Al Qaeda Strikes Back.” Foreign Affairs 86.3 (2007): 24-40.

Sageman, Marc. Understanding Terror Networks. Philadelphia, PA: U of Pennsylvania, 2004.

Speckhard, Anne, and Khapta Akhmedova. "Black Widows: The Chechen Female Suicide Terrorists." Female Suicide Terrorists. Ed. Yoram Schweitzer. Tel Aviv, Israel: Jaffe Center Publication, 2006. 7I.

Stack, Alisa. "Zombies and Black Widows." Women, Gender, and Terrorism. Ed. Laura Sjoberg and Caron Gentry. Athens, GA: U of Georgia, 2009. 87.

Stack-O'Connor, Alisa. "Picked Last: Women and Terrorism.” Joint Force Quarterly 44 (2007): 99.

“Terror in Moscow.” CBS News. N.p., 24 Oct. 2003.

Thatcher, Margaret. "Speech to American Bar Association." London. I5 July I985. Margaret Thatcher Association. 
9 Tsvetkova, Maria. "Second Suicide Bomber in Russia's Volgograd Kills I4 on Bus." Reuters. N.p., 30 Dec. 2013.

"Women in War." The International Committee of the Red Cross in Iraq. N.p., Mar. 2009. 